\title{
Literowanie luk codzienności. Konteksty narracji o afazji
}

Klaudia Muca

TEKSTY DRUGIE 2016, NR 5, S. 427-440

DOI: $10.18318 /$ td.2016.5.27

$\mathbf{N}_{\mathrm{s}}^{\mathrm{i}}$ ie mamy już początków"1 - w ten sposób George Steiner rozpoczął Gramatyki tworzenia - książkę o tym, jak słowa kształtują rzeczywistość. Problem punktu wyjścia, źródła czy pierwszego aktu inicjującego jakieś zjawisko lub czynność jest kwestią gramatyki dopiero językowa artykulacja doświadczenia pozwala je uporządkować, ująć jako ciąg przyczynowo-skutkowy z wyraźnie zaznaczonym początkiem, rozumianym jako moment przełomu, epistemicznego cięcia, które każe wyodrębnić z chaosu zdarzeń coś, co ten chaos będzie w stanie retroaktywnie uporządkować. Początek istnieje więc jako konieczny element naszych narracji o świecie, jest jedną z metakategorii naszego myślenia - wokół niej organizuje się jakiś ład (choćby tymczasowy, ład „na własny użytek").

Steiner jest patronem mówienia i myślenia o rzeczywistości jako o przedmiocie języka. Przywołane wyżej
Klaudia Muca -

biogram na s. 404.

1 G. Steiner Gramatyki tworzenia. Na podstawie wygłoszonych w roku 1990 wykładów imienia Gifforda, Zysk i S-ka, Poznań 2004, s. 7. 
stwierdzenie amerykańskiego filozofa nazywa zjawisko wyparcia z pola świadomości współczesnego człowieka narracji o początkach przez narracje o zmierzchu kultury europejskiej. Na obecnym etapie rozwoju myśli wszelkie genealogie to projekty utopijne - to przekonanie jest źródłem znużenia kultura, inercji woli tworzenia, kapitulacji na rzecz praktyki odtwarzania. Odległość początku od aktualności jest zbyt duża, świadomość gubi się w wytwarzanych przez samą siebie powtórzeniach genezy.

Relacji między początkiem i aktualnością nie da się opisać jako prostego przechodzenia jednych zdarzeń czy doświadczeń w inne. Narracja próbująca objać przedział czasu, wyznaczony przez te dwa momenty, to projekt nie do zrealizowania, utopia języka, który stara się uporządkować bieg życia, nadać mu sens czy - innymi słowy - stworzyć jego gramatykę. Zawsze pozostaje jakiś nadmiar, coś, co nie zyskuje nazwy, nie osadza się w świadomości człowieka lub zostaje wyparte, zepchnięte poza jej granice. Mówienie jest więc w gruncie rzeczy zgodą na stratę. Język próbuje radzić sobie z chaosem zdarzeń, tworząc pewne semantyczne konstelacje, czyli słowa, zdania i większe całości (opowieści), nadaje porządek doświadczeniu.

Steinerowskie rozważania na temat początków i tworzenia to jeden z punktów zaczepienia narracji o zjawisku, którego analiza pozwala powrócić do opowieści o genezie oraz pytania o rolę języka w każdym procesie genealogicznym. Tym zjawiskiem jest afazja - nie do końca rozpoznany, trudny do systematycznego opisu fenomen całkowitej lub częściowej utraty pamięci języka i pamięci zdarzeń. Afazja jest nowym początkiem świadomości człowieka, jednostkowym precedensem, który wymaga od podmiotu ogromnego wysiłku woli i intelektu, by ponownie nawiązać łączność ze światem. W przypadku afatyków proces odzyskiwania wiedzy o funkcjonowaniu systemu znaków jest niemal tożsamy z procesem odzyskiwania wiedzy o sobie, odpamiętywania faktów z przeszłości, tworzenia podstaw nowej autonarracji - w wyniku uszkodzenia mózgu „stara” narracja została w gwałtowny sposób przerwana. Badanie świadectw afazji, czyli literackich i nieliterackich tekstów opisujących to doświadczenie, jest badaniem genezy języka i poczucia tożsamości w sytuacji życiowego ekstremum, jakim jest niemożność porozumiewania się z innymi, wyrażania myśli i uczuć, zapisywania i zapamiętywania zdarzeń. Autorzy i autorki tych świadectw utracili „władzę nad słowem” i dzięki pisaniu o trudnym doświadczeniu utraty starali się tę władzę odzyskać².

2 „Każde ze słów budziło rój żywych, zmieniających się, wyraziście odbieranych wspomnień. Władać takim słowem oznaczało możliwość wywołania dowolnego wrażenia z przeszłości, 


\section{Afazja jako problem poznawczy}

Afazję można rozpatrywać w trzech kontekstach. Kontekst podstawowy to neurolingwistyka, czyli badania nad afazją jako patologicznym stanem umysłu, wynikającym z organicznego uszkodzenia mózgu ${ }^{3}$. Według Marthy Taylor Sarno - amerykańskiej badaczki zajmującej się neurogennymi zaburzeniami mowy i zdolności posługiwania się znakami systemu językowego ${ }^{4}$ - dochodzi wówczas do rozpadu podstawowej komunikatywnej funkcji języka, „w rezultacie czego chorzy mają trudności z mówieniem, pisaniem, czytaniem oraz rozumieniem wypowiedzi innych osób, precyzowaniem czasu, określaniem przestrzeni oraz rozpoznawaniem przedmiotów"5. W polskich badaniach afazjologicznych najbardziej rozpowszechniona jest definicja Marii Pąchalskiej:

Afazja jest syndromem oznaczającym dezintegrację procesu przetwarzania informacji, czyli zaburzeniem zdolności „dekodowania” i/lub „kodowania" różnorodnych symboli niejęzykowych i/lub językowych występujących w danym języku, kręgu kulturowym czy wspólnocie komunikatywnej, wywołane w następstwie organicznego uszkodzenia ośrodkowego układu nerwowego. ${ }^{6}$

pozwalało ujmować istotę rzeczy, tworzyć, panować nad życiem. Wszystko to w jego przypadku zniknęło i to bezpowrotnie." - to fragment książki Świat utracony i odzyskany. Historia pewnego zranienia Aleksandra R. Łurii - książki o L. Zasieckim - żołnierzu, który w czasie II wojny światowej został postrzelony w głowę. W wyniku postrzału doznał uszkodzenia mózgu i afazji. Swoje doświadczenia spisywał przez 25 lat. Książka jest dwugłosem na temat afazji - składa się z fragmentów pamiętnika Zasieckiego i komentarzy Łurii. Przedstawia trudności, z jakimi mierzy się afatyk, oraz trudności, jakich doświadcza badacz afazji jako egzystencjalnego fenomenu, do opisu którego nie wystarcza język medyczny. Zob. A.R. Łuria Świat utracony i odzyskany. Historia pewnego zranienia, przeł. A. Kowaliszyn, PWN, Warszawa 1976.

3 Najpopularniejszym i najbardziej kompletnym kompendium wiedzy o afazji jako problemie neuronauk jest Afazjologia Marii Pąchalskiej (zob. M. Pąchalska Afazjologia, PWN, Warszawa 1999). Koniecznym uzupełnieniem bibliografii na temat afazji są prace Mariusza Maruszewskiego (zob. zwłaszcza: M. Maruszewski Afazja. Zagadnienia teorii i terapii, PWN, Warszawa 1966; Mowa a mózg. Zagadnienia neuropsychologiczne, PWN, Warszawa 1970; Chory z afazjq i jego usprawnienie, Nasza Księgarnia, Warszawa 1974).

4 Zob. np.: M.T. Sarno Acqiured Aphasia, 3rd edition, Cambridge University Press, Cambridge, MA 1998; J. Peters, M.T. Sarno The Aphasia Handbook. A Guide for Stroke and Injury Survivors and Their Families, National Aphasia Association, Scarsdale 2004.

5 Cyt. za: M. Pąchalska Afazjologia, s. 27.

6 Tamże. 
Rodzaj i stopień „zakłóceń językowych” zależy od rozległości uszkodzeń mózgu, w wyniku których dochodzi do osłabienia lub zaniku tzw. engramów, czyli śladów pamięciowych, odpowiedzialnych za dekodowanie lub kodowanie znaków określonego systemu semiotycznego ${ }^{7}$. W ten właśnie sposób w umyśle afatyka rodzi się chaos. Można go opisać jako zespół różnego rodzaju zaburzeń i zerwań, takich jak zmiany zachodzące w pamięci oraz zdolności przekazywania komunikatów - ostatnia zmiana jest konsekwencją właściwego stanom afazyjnym rozerwania połączenia signifiant i signifié. Nauka i praktyka języka służą przywróceniu tego połączenia.

Drugi kontekst to badania lingwistyczne. Jednym z pionierów badań nad afazyjnymi zaburzeniami mowy wśród lingwistów był Roman Jakobson, który na podstawie analizy językowych symptomów afazji rozpoznał i opisał dwa podstawowe mechanizmy kształtowania się wypowiedzi: metonimię i metaforę . Według Jakobsona zadaniem lingwistyki jest nie tylko badanie realizacji wypowiedzi zgodnych z określonym systemem językowym, ale także patologii tych wypowiedzi, „zakłóceń mowy”., Żeby badać należycie jakiekolwiek załamanie w procesie porozumiewania się, trzeba rozumieć naturę i strukturę środka porozumiewania się, który w danym wypadku przestał funkcjonować. Lingwistyka zajmuje się językiem we wszystkich jego stanach: językiem w działaniu, językiem w ruchu [...], językiem w powstaniu i językiem w rozkładzie" . Wszystkie wskazane przez Jakobsona stany języka można rozpoznać na podstawie badań nad afazją. Stadia odzyskiwania zdolności komunikowania się są przy tym etapami uzyskiwania (tworzenia) tożsamości i świadomości jednostkowej, zgodnie z często przywoływaną przez Jakobsona i jego naukową spadkobierczynię - Marię Renatę Mayenową - hipotezą Edwarda Sapira i Benjamina Lee Whorfa o ścisłej zależności między kodem i „formą myśli” czy - posługując się nowszą terminologią - o performatywnym, modelującym potencjale znaków językowych ${ }^{10}$.

7 Tamże, s. 17 i 28.

8 R. Jakobson Dwa aspekty języka i dwa typy zakłóceń afatycznych, w: tegoż W poszukiwaniu istoty języka: wybór pism, red. M.R. Mayenowa, t. 2, PIW, Warszawa 1989, s. 150-175.

Tamże, s. 150.

10 Por. M.R. Mayenowa, Wstęp, w: R. Jakobson, W poszukiwaniu..., s. 6 i n. Teoria Sapira-Whorfa, sformułowana w latach 30. XX wieku, jest wyraźną cezurą w rozwoju lingwistyki, jednak obecnie ma ona już charakter historyczny. Istnieje wiele nowszych ujęć zagadnienia zależności struktury języka i obrazu rzeczywistości - dość obszerną ich prezentację można znaleźć 
Wreszcie trzeci kontekst, najszerszy - afazja w ujęciu antropologicznym. Chodzi o rozpoznanie tego zjawiska jako złożonego problemu poznawczego, który wymusza skupienie się na najbardziej podstawowych dla funkcjonowania człowieka zagadnieniach, takich jak tożsamość i samoświadomość, język i komunikacja, doświadczenie choroby i procesu odzyskiwania zdrowia (który nota bene jest procesem permanentnym i niefinalnym - uszkodzenia mózgu są zazwyczaj nieodwracalne, co czyni z życia afatyka nieustanną praktykę powtarzania czynności, wiedzy, „imion rzeczy” itd., w celu poprawy jakości życia), znaczenie pamięci i przeszłości, czyli tego, co utracone lub okaleczone (niepełne, nieprzystające do siebie, rozproszone). Afazja powoduje przerwanie ciągłości życia jednostki; to, co przed chorobą, zostaje radykalnie oddzielone od tego, co po. Moment zachorowania jest więc w gruncie rzeczy momentem inicjującym narodziny nowej tożsamości i powstawanie odpowiednich form jej ekspresji (nie tylko językowej) ${ }^{11}$. Z chaosu znaków, ułamków wspomnień i fragmentów historii wyłania się więc nowy świat i nowy człowiek.

To wyłanianie się podmiotu z chaosu znaków ma początkowo charakter metodycznej nauki grafii, gramatyki, zasad łączenia słów w większe zespoły składniowo-semantyczne. Bardziej twórcze wykorzystanie języka zaczyna się później, kiedy poczucie ponownego zadomowienia w systemie językowym jest silniejsze, kiedy podmiot staje się bardziej świadomym użytkownikiem języka, czyli wtedy, gdy zaczyna mówić o języku, gdy pojawia się metarefleksja. Celem i zarazem warunkiem możliwości komunikowania czegokolwiek jest odzyskanie podmiotu dla języka. Język jest gotową formą, ale nie wiadomo, kim jest ten, kto chce się w nim wypowiedzieć, odnaleźć, określić. Narracja wspomaga i przyspiesza proces autoanalizy i autoekspresji. Podmiot stopniowo odzyskuje pozycję tego, kto nazywa i nadaje znaczenia. To, co uległo dezintegracji w wyniku uszkodzenia mózgu, scala się, przy czym nie możemy uznać, że to scalenie umożliwia podjęcie przerwanych przez wylew czy udar wątków narracji tożsamościowej. Możliwe jest nawiązanie do przeszłości,

w zbiorze /ęzykowy obraz świata (zob. /ęzykowy obraz świata, red. B. Paprocka, wyd. 2, Wydawnictwo UMCS, Lublin 1999).

11 To moment "brzemienny", moment "bólów porodowych" (Wehen) - w ten sposób w jednym ze swoich esejów Walter Benjamin określa "narodziny nowych postaci języka" w procesie historycznego rozwoju (W. Benjamin Zadanie tłumacza, w: tegoż Konstelacje. Wybór tekstów, przeł. A. Lipszyc, A. Wołkowicz, Wydawnictwo UJ, Kraków 2012, s. 23-36; por. A. Lipszyc Sprawiedliwośćna końcu języka. Czytanie Waltera Benjamina, Universitas, Kraków 2012, s. 88-89 (Horyzonty Nowoczesności, t. 97)). 
jej częściowe odpomnienie czy odtworzenie na podstawie śladów (np. zdjęć, dokumentów czy opowieści bliskich), jednak scalenie dotyczy tego, co nowe, tych elementów wiedzy i doświadczenia, które pojawiają się podczas odzyskiwania fizycznej i intelektualnej sprawności po uszkodzeniu mózgu.

Afazja ma swoją historię - to historia biegnąca dwoma nurtami. Nurt pierwszy można określić naukowym. Obejmuje on refleksję neurologiczną (M. Pąchalska), neuropsychologiczną (M. Maruszewski), lingwistyczną (A. Łuria, R. Jakobson) i filozoficzną (H. Bergson) ${ }^{\mathbf{1 2}}$. Refleksja ta tworzy makrohistorię afazji jako choroby, syndromu czy intelektualnego regresu, jest zbiorem obiektywnych twierdzeń, sformułowanych na podstawie wybranego materiału egzemplarycznego. Punktem wyjścia tej naukowej narracji jest dychotomia „normalne” - „patologiczne”. Rozpoznanie stanu afatyka polega więc na charakterystyce stanu patologicznego przez odniesienie do stanu uznawanego za normalny. Podmiot doświadczenia choroby zdaje się w tym naukowym dyskursie nieobecny, funkcjonuje jako przedmiot dyskursu, zostaje przedstawiony jako bierny uczestnik procesu diagnostycznego. Wskazana wyżej dychotomia oraz przedmiotowe traktowanie podmiotu-pacjenta były wielokrotnie poddawane krytyce ${ }^{13}$. Zupełnie inna postawa charakteryzuje narracje wchodzące w skład drugiego nurtu historii afazji. To nurt jednostkowych mikrohistorii, skupionych na rozpoznaniu specyfiki podmiotowego doświadczenia, będących jednocześnie zbiorem informacji o tym doświadczeniu, rodzajem autoterapii, umożliwiającej szybszy powrót do świata znaków, oraz szansą na sproblematyzowanie przeżyć, zinterpretowanie ich i stworzenie tekstu doświadczenia, czyli przedstawienia afazji, stanowiącego dowód bardzo świadomie podejmowanej próby odzyskania władzy nad słowem. Teksty doświadczenia tworzą laboratorium form i treści, które biorą bezpośredni udział nie tylko w kształtowaniu środowiska dla myśli i aktywności

12 Bergson zapoznał się z pracami na temat afazji przed przystąpieniem do pisania książki Materia i pamięć. O stosunku ciała do ducha. W jednej z notatek filozofa możemy przeczytać: „Literatura afazji jest olbrzymia. Przez 5 lat nad nią pracowałem. Doszedłem do wniosku, że stosunek między faktem psychologicznym a jego podłożem mózgowem nie odpowiada żadnemu z gotowych pojęć dostarczanych przez filozofię". Ten fragment zapisków filozofa przytacza tłumacz Materii i pamięci... - Władysław Filewicz. Zob. H. Bergson Materia i pamięć. O Stosunku ciała do ducha, przeł. W. Filewicz, Wydawnictwo Vis-à-vis/Etiuda, Kraków 2015, s. 5.

Za najważniejszych krytyków dyskursu o chorobie uznaję Susan Sontag (S. Sontag Choroba jako metafora. AIDS i jego metafory, przeł. L. Anders, PIW, Warszawa 1999) i Georgesa Canguilhema (G. Canguilhem Normalne i patologiczne, przeł. P. Pieniążek, słowo/obraz terytoria, Gdańsk 2000). 
twórczej, ale przede wszystkim w kształtowaniu przestrzeni dla podmiotu i jego działania, mającego na celu powtórzenie procesu poiesis siebie. W tym procesie „ja" dąży do odzyskania poczucia tożsamości i życiowej równowagi po doświadczeniu, które radykalnie zmieniło „bieg życia”, zerwało ciągłość narracji tożsamościowej, przekształciło sposoby rozumienia siebie i rzeczywistości. W świadomości afatyka narodził się chaos, wiedza na temat świata uległa dekompozycji, dlatego tak istotne jest podjęcie działania, które ułoży $\mathrm{z}$ dostępnych afatykowi form i treści nową kompozycję - takim działaniem jest właśnie tworzenie tekstu doświadczenia. Podmiot afatyczny musi raz jeszcze opowiedzieć świat samemu sobie. Treścią opowieści jest także on sam - „ja” doświadczające „dysfunkcji intelektu”, w wyniku której utraciło zdolność (auto)narracji, podejmujące próbę stworzenia spójnego obrazu siebie $\mathrm{z}$ wielu rozproszonych fragmentów.

\section{Idiom doświadczenia. Twórczość Karoliny Wiktor}

Autorką określenia afazji jako „dysfunkcji intelektu” jest Karolina Wiktor, która opisała swoje afazyjne doświadczenie w książce Wołga przez Afazję $e^{14}$. Można też spotkać takie określenia jak „kolaps intelektu”, ,afazja logosu” (Oka-leczenie Z. Fajfera i K. Bazarnik), „wybuch mózgu” (K. Wiktor), ,zakłócenie językowe” (R. Jakobson) czy „dezintegracja procesu przetwarzania informacji” (M. Pąchalska). Wszystkie te lapidarne określenia afazji wskazują na koniec jakiegoś stanu i początek innego. Przejście z jednego stanu w drugi ma gwałtowny charakter, jest zerwaniem, rozdzieleniem aktualności na dwa nieprzystające do siebie wymiary życia - wymiar sprzed „wybuchu” (dostęp do niego jest utrudniony) i po nim (czyli „tu i teraz” świadomości). Innym aspektem afazji, na który wskazują jej definicje i parafrazy, jest skutek „kolapsu intelektu” rozdrobnienie świata, zerwanie związków logicznych, przyczynowo-skutkowych i motywacyjnych między elementami wiedzy o rzeczywistości.

Jednym z podstawowych elementów osobistej mikrohistorii doświadczenia jest właśnie stworzenie jego adekwatnej nazwy, peryfrazy, która pozwalałaby to doświadczenie dookreślić i w ten sposób ułatwić jego zrozumienie. W naszej rozmowie Wiktor posłużyła się również określeniem afazji jako „absolutnego duchowego przełomu". Ta peryfraza jest jedną z wielu słownych aktualizacji wyobrażenia końca czegoś i rozpoczynania się czegoś nowego, pojawiających się w twórczości Wiktor. Wyobrażenie to staje się podstawą

14 K. Wiktor Wołgą przez Afazję, Korporacja Ha!art, Zachęta, Kraków-Warszawa 2014. 
narracji o krainie Afazji, wyznacza symboliczny początek odzyskiwania sprawności fizycznej i intelektualnej po udarze, motywuje do wypełnienia pustki,jaka powstała w wyniku utraty pamięci zdarzeń i zdolności ich językowego reprezentowania. Przełom oznacza w tym kontekście przerwanie życia w jego duchowym wymiarze, związane z uszkodzeniem mózgu jako miejsca, gdzie ta duchowość miała swoje źródło; przełom nie ma charakteru łagodnej zmiany, „wrzuca” podmiot w doświadczenie, które jest egzystencjalnym szokiem.

Przełom rodzi także możliwość. Od 28 sierpnia 2009 roku - dnia, w którym Karolina Wiktor doznała udaru w wyniku pęknięcia tętniaka mózgu minęło prawie siedem lat. W jej tekstach i pracach artystycznych retorykę końca i przełomu stopniowo zastępowała retoryka nadziei i szansy, miejsce szoku zajęła afirmacja doświadczenia, konieczna do podjęcia opowieści o tym doświadczeniu. To właśnie dzięki opowieści potencjał przełomu mógł zostać wykorzystany.

W procesie oswajania się z doświadczeniem „absolutnego duchowego przełomu" istotną rolę odegrał i odgrywa nadal tekst jako model strukturyzowania tego doświadczenia lub - innymi słowy - jego dyskursywna rama. Dzięki narracji strumień zdarzeń może zyskać jakiś porządek, a jej finał, czyli tekst, może zagwarantować podmiotom tych zdarzeń powrót do nich, możliwość wspominania i tworzenia wiedzy o przeszłości. Tekst poza funkcją utrwalania zdarzeń i doświadczeń pełni też inną istotną funkcję - pozwala badać doświadczenie, jest czymś w rodzaju laboratorium, w którym testuje się możliwości werbalizacji „duchowych przełomów” oraz tworzy nowe sposoby zastępowania doświadczeń za pomocą słów. W przypadku Karoliny Wiktor tekst pełnił jeszcze jedną istotną funkcję - był środkiem wspomagającym rehabilitację w jej wymiarze fizycznym (poprawa sprawności dłoni, odzyskiwanie umiejętności skupiania się na jakimś przedmiocie lub czynności) oraz mentalnym (pisanie jako znak odzyskiwania zdolności komunikacyjnych, jako szansa na przedstawienie doświadczenia i odzyskanie łączności ze światem zewnętrznym poprzez język).

Przełom określony jako koniec czegoś powoduje powstanie pustki - tworzenie tekstu doświadczenia jest sposobem na jej wypełnienie. Wiktor często określa swoją twórczość jako „pracę na literze”. Litera jako najmniejsza, materialna cząstka języka jest podstawą, na której opiera się tekst doświadczenia, i właśnie dzięki literze powstałe w wyniku uszkodzenia mózgu intelektualne i pamięciowe luki mogą zostać wypełnione. W trakcie przygotowywania wystawy o afazji w Atlasie Sztuki w Łodzi Wiktor stworzyła Alfabet brakującej 
czcionki, czyli własny model czcionki, kompletny, jeśli chodzi o liczbę liter, niekompletny, jeśli chodzi o kształty - litery nie są domknięte, wyglądają tak, jak gdyby ktoś zaczął je rysować i w pewnym momencie oderwał ołówek od kartki15. Ten artystyczny projekt przedstawia kilka ważnych aspektów doświadczenia afazji. Po pierwsze, zwraca uwagę na doświadczenie braku, pustki, rozdrobnienia, które pojawiają się w świecie po udarze; po drugie, pozwala zrozumieć dynamikę tworzenia tekstu doświadczenia afazji - to tworzenie wymaga swoistej „pracy u podstaw”, nauki języka od nowa, poznawanie przybiera więc postać „literowania”, czyli powolnego i skrupulatnego przyglądania się światu przez pryzmat znaku ${ }^{\mathbf{1 6}}$; po trzecie, uświadamia inwencyjny potencjał języka i jego poszczególnych elementów - język w pracach Wiktor staje się przedmiotem artystycznym, który wchodzi w rozmaite relacje ze znaczeniem i nie jest temu znaczeniu jako nośnik podporządkowany. Wiktor przykłada wagę nie tylko do treści tekstu doświadczenia, lecz także do jego formy oraz środków umożliwiających wytworzenie tego tekstu. Korzysta z bardzo różnych modeli przekazu, np. wpisu blogowego, poezji wizualnej, wywiadu wizualnego, fotografii czy wykładu, co pozwala wykorzystać potencjał zmiany medium (remediacji) do stworzenia narracji o „doświadczeniu duchowego przełomu".

Strumień form i treści, jakie pojawiają się w twórczości Karoliny Wiktor, ma heterogeniczny charakter, składa się z fragmentów, słownych kolaży, nowych elementów grafii i nieoczywistych, niefiguralnych przedstawień wizualnych. Pierwszym projektem artystycznym Wiktor był blog, który zaczęła prowadzić rok po udarze ${ }^{17}$. Blog jest słowno-audiowizualną hybrydą, łączącą tekst stworzony przez artystkę oraz różnego rodzaju linki, odsyłające w różne miejsca wirtualnej przestrzeni (np. linki do nagrań w serwisie YouTube),

15 Wystawa La déchirure. Rozdarcie była prezentowana od 15 stycznia do 28 lutego 2016 roku w łódzkim Atlasie Sztuki. Kuratorem wystawy był Andrzej Turowski. Wystawa składała się z trzech części, w których prezentowane były prace Moniki Sosnowskiej, Marka Szczęsnego i Karoliny Wiktor.

16 Sformułowanie to nawiązuje do tytułu znanej książki Maxa Bensego Świat przez pryzmat znaku (zob. M. Bense Świat przez pryzmat znaku, przeł. J. Garewicz, PIW, Warszawa 1980).

17 Adres bloga: http://afazja.blogspot.com/. Obecnie blog funkcjonuje pod nazwą "Kultura i Neuronauka". Jest stroną autorskiego projektu Wiktor - konferencji Kultura i Neuronauka którego celem jest popularyzowanie wiedzy o mózgu, neurofizjologii, profilaktyce zaburzeń umysłowych oraz sztuce tworzonej przez osoby niepełnosprawne. Pierwsza edycja konferencji odbyła się 25 października 2014 roku w Warszawie, druga - w tym roku w dniach 21-23 października. 
a także przestrzeni symbolicznej (np. nawiązania do prozy braci Strugackich czy cytaty z twórczości Tadeusza Peipera). Pierwszy internetowy wpis pojawił się 10 kwietnia 2010 roku. Wybrane wpisy blogowe zostały opracowane i wydane w książce Wołga przez Afazję. Jest ona w pewnym sensie powtórzeniem, a zarazem przedłużeniem blogowej narracji, połączonym ze zmianą medium. Zmiana ta oznaczała utratę możliwości szybkiego zapoznania się z proponowanymi przez Wiktor intertekstami, jednak ta utrata została zrekompensowana przez przejrzystość układu treści w książce, pozwalającą skupić się na osobistej narracji autorki i na sposobach, jakimi opisuje doświadczenie afazji.

Wołga przez Afazję zachowuje strukturę blogowych wpisów. Jest notatnikiem z podróży po krainie Afazji, dokumentuje odkrywanie jej szczególnej topografii - to topografia emocji, zachowań, umiejętności, ogólnego stanu psychofizycznego. W tekstowym krajobrazie Afazji istotne są też miejsca, w których następuje przerwanie narracji. Te miejsca zostają zaznaczone za pomocą grupy znaków interpunkcyjnych, tworzących nowy typ grafii z nowym symbolicznym kodem. Wybrane kompozycje znaków interpunkcyjnych zgodnie ze stworzoną przez autorkę wykładnią kodu oznaczają: „...." - zwyczajne twierdzenie, ,",," - epizod twierdzenia, ,----" - długotrwałe twierdzenie, , ????” - zwyczajne zdziwienie, „)*(" - uśmiech ${ }^{\mathbf{1 8}}$. Znaczenie poszczególnych układów znaków Wiktor opisała na swoim blogu we wpisie z 12 grudnia 2010 roku. Nowy typ grafii reprezentuje te miejsca narracji tożsamościowej, w których nastąpiło jej zatrzymanie. Jest ono związane z niemożnością wynikającą z uszkodzenia struktur mózgowych, odpowiedzialnych za kodowanie informacji. Nie jest jednak końcem narracji, jedynie przystankiem, momentem zastanowienia i poszukiwania innych słów na określenie jakiegoś elementu krajobrazu Afazji.

Wiedza na temat tej krainy jest porządkowana dzięki narracji. Tekst stawał się jednocześnie laboratorium i archiwum; umożliwiał rozwijanie refleksji nad doświadczeniem, opracowywanie nowych sposobów opowiadania o nim, oraz gromadzenie zdobytej wiedzy na temat afazji, tworzenie informacyjnej bazy dla myśli i dalszej twórczości. To tekstowe zaplecze ułatwia radzenie sobie z afazją, wspomaga pracę podmiotu, jest wytworem aktywnej jednostki, która próbuje zrozumieć psychiczny i fizyczny stan, w jakim się znalazła. Tekst doświadczenia wymaga stworzenia nowego języka, bliższego opisywanym przeżyciom. „Kody realu są dla mnie ciągle drewniane” - wpis o takiej treści pojawił się na blogu Wiktor 12 marca 2012 roku; „[...] wszystkie kody

18 Zapis znaków podaję z zachowaniem oryginalnej czcionki. 
i narzędzia komunikacji są nieaktywne" - czytamy w jednej z części Wołga przez Afazję, zatytułowanej SATYSFAKCJA z NIEMOŻLIWOŚCI, czyli kreatywność w świecie niesprawności. Afazja jest doświadczeniem utraty gramatyki w sensie ścisłym, czyli znajomości reguł tworzenia poprawnych składniowo i semantycznie komunikatów. Wiąże się także z utratą znajomości gramatyki rozumianej za Steinerem jako „zestrojona organizacja percepcji, refleksji i doświadczenia, system nerwowy świadomości, w momencie gdy komunikuje się ona ze sobą i innymi"19. Afazjanin musi uczyć się reguł obu gramatyk od nowa. W przypadku Wiktor nauka staje się procesem twórczym, popisem kreatywności podmiotu, który stara się samodzielnie zdobyć narzędzia pozwalające na zrozumienie doświadczenia. Autorka Wołga przez Afazję stworzyła swój własny idiom, niepowtarzalny styl opisu przeżyć. Ten idiom powstał w wyniku przekształcenia "drewnianych kodów" semiotycznych, za pomocą których porozumiewamy się. Językowe kody i reguły stały się bardziej elastyczne, a poszczególne elementy języka - morfemy, litery, słowa - zaczęły być traktowane nie jako neutralne nośniki znaczenia, ale jako autonomiczne elementy symbolicznego uniwersum, które mogą stać się przedmiotami artystycznymi, służącymi reprezentacji doświadczenia afazji.

Na podstawie twórczości Karoliny Witor (traktowanej en bloc) można zrekonstruować swoistą genetyczną fabułę, przedstawiającą etapy zmagania się z „dysfunkcją intelektu" i powstawania stylu jej opisu. Na początku doszło do „wybuchu”, w wyniku którego nastąpiły wylew i utrata pamięci języka; ten stan można określić po prostu jako chaos, związany z zanikiem zdolności komunikowania, wymiany informacji. Terapia, której towarzyszyły pierwsze quasi-literackie wprawki na blogu, to etap „kosmogoniczny”, etap powstawania świata, próba powołania i ukształtowania na nowo przestrzeni podmiotowej aktywności, wspierającej się na pamięci oraz języku jako podstawowym narzędziu ekspresji myśli. Ta kosmogonia trwa nadal. W 2013 roku powstał nowy blog Wiktor, noszący nazwę literowanie obrazu ${ }^{20}$, na którym autorka umieszcza swoje wizualne kompozycje ze słów.

Opisana wyżej fabuła genetyczna powstaje przez „literowanie luk codzienności"21. W ten właśnie sposób Karolina Wiktor określa cel swoich prac

19

G. Steiner Gramatyki tworzenia..., s. 11.

Adres bloga: http://poezjawizualna.blogspot.com/ (24.11.2016).

Ta formuła pojawiła się w Wołgą przez Afazję. Taki tytuł nosi też wywiad z Karoliną Wiktor, który przeprowadził Łukasz Musielak. Rozmowa jest dostępna on-line pod adresem: http://issuu. com/karolinawiktor/docs/wywiad_wizualny_2095a642f66dbo/1 (24.11.2016). 
- mają one wypełnić braki, puste miejsca pamięci i świadomości, które powstały w wyniku afazji. Swoją praktykę twórczą z kolei nazywa pisaniem wizualnym, zwracając szczególną uwagę na rozmieszczenie liter w przestrzeni grafiki czy ich układ względem siebie. Litera w danej kompozycji ma przede wszystkim „wyglądać”, prezentować się jako element dzieła, uwolniony od przymusu reprezentacji, obdarzony jedynie prawem sugerowania. Sugestia znaczenia zastępuje miejsce reprezentacji. Słowa w poezji wizualnej Wiktor uwikłane są w swoistą grę z signifié, czasem je naśladują (przedrzeźniając można powiedzieć - czyli próbując powtórzyć desygnat w jakiś obrazowy sposób), czasem dokonują jego dekonstrukcji, jak gdyby sprawdzenia możliwości słowa jako materialnego znaku, podejmującego dialog z przypisanym mu znaczeniem.

Cechą charakterystyczną wizualnych kompozycji Karoliny Wiktor jest wysoki stopień zgeometryzowania. Przestrzenie, w których pojawia się treść, są zwykle oddzielone od siebie w obrębie pewnej całości, zaznaczona jest ich odrębność. Zazwyczaj nie są to litery czy słowa „w rozsypce” - występują obok siebie, tworząc jakiś przekaz, są odpowiednio skomponowane, przy czym chodzi tu nie tyle o kompozycję słowa z liter, do której jesteśmy przyzwyczajeni w ramach pewnej strukturalno-hierarchicznej właściwości systemu językowego, ile o kompozycję, w której litery mogą stać się samodzielne, zostać uwolnione od pewnego przymusu relacyjności. Litera może wyodrębnić się ze słowa - w ten sposób funkcjonuje jako znak w każdej chwili zdolny do wejścia w nową semantyczną relację.

Wymienione do tej pory trzy główne projekty artystyczne Karoliny Wiktor - blog i książka Wołga przez Afazję, literowanie obrazu, czyli blog z poezją wizualną, oraz Alfabet brakującej czcionki - można potraktować jako konstelacyjną całość, dzieła ściśle ze sobą związane ze względu na to samo źródło - tym źródłem jest doświadczenie „absolutnego duchowego przełomu”. Afazyjny brak - niepamięć języka, częściowa utrata wspomnień, problemy z artykułowaniem myśli, samotność i poczucie niezrozumienia, towarzyszące afatykowi w ciągu pierwszych miesięcy po wylewie - był sytuacją epistemologicznego kryzysu, który okazał się kryzysem tymczasowym, możliwym do „przeliterowania". Każdy przypadek afazji ma swoją specyfikę, każdy tekst doświadczenia jest rodzajem idiomu, ściśle związanego z wypowiadającym i/lub zapisującym ten tekst podmiotem, z jego emocjami, myślami i przeżyciami.

Dzięki aktywności twórczej zwiększa się znacznie nasza aktywność poznawcza. Pisanie dla afatyków może być terapią pamięci - taką funkcję spełniał Baltazar. Autobiografia (2006) Sławomira Mrożka; może przyczynić 
się do popularyzacji wiedzy o "dysfunkcjach intelektu” - taki był cel My Stroke of Insight (2009) Jill Bolte Taylor - dziennika afazji, który powstał już po odzyskaniu sprawności intelektualnej i fizycznej; może być ulgą w cierpieniu wynikającym z braku znaczących postępów w nauce gramatyki języka i gramatyki kultury po uszkodzeniu mózgu - pisanie było ulgą dla Zasieckiego, autora Historii pewnego zranienia; może też pomóc w rozpoznawaniu afazji jako stanu ciała i umysłu - to jedna z funkcji pisania w twórczości Karoliny Wiktor. Tworzenie tekstu doświadczenia to z jednej strony konfrontacja z tym doświadczeniem, z drugiej - jego afirmacja. Dla Karoliny Wiktor - głównej bohaterki tego tekstu oraz publikowanego wywiadu - kraina Afazji „nie jest odległą i bladą repliką świata rzeczywistego, tylko nowym, lecz pełnoprawnym jego wymiarem"22. Tę krainę da się opisać, istnieje ona jako pewien egzystencjalny fakt, nakłada na ,ja” wiele ograniczeń, ale nie zamyka w wewnętrznej twierdzy. Opisywanie doświadczenia jest symbolicznym gestem przekroczenia granic tej twierdzy. Każde wypowiedziane lub zapisane słowo zbliża podmiot do dokładniejszego rozpoznania i zrozumienia doświadczenia "absolutnego duchowego przełomu".

\section{* * *}

Wywiad W pończosze istota jest... to zapis rozmowy, która odbyła się 19 i 20 lutego tego roku w Warszawie. Poprosiłam Karolinę Wiktor o spotkanie, ponieważ chciałam zapytać o kilka kwestii związanych z jej twórczością i uzupełnić brakujące informacje potrzebne do napisania jednego z rozdziałów pracy magisterskiej. Wywiad badawczy zmienił się w rozmowę o przeżywaniu afazji, pisaniu, książkach, mózgu i profilaktyce zaburzeń jego funkcjonowania, o niezwykłych artystach, pisarzach i naukowcach. Za tę wyjątkową intelektualną przygodę chciałabym mojej Rozmówczyni serdecznie podziękować.

To zdanie jest niemal dosłownym cytatem ze wstępu do polskiego wydania książki Davida Olsona Papierowy świat. Pojęciowe i poznawcze implikacje pisania i czytania. W oryginale zamiast "krainy Afazji” pojawia się „papierowy świat”. Zob. G. Godlewski David Olson, odkrywca „papierowego świata", w: D. Olson Papierowy świat. Pojęciowe i poznawcze implikacje pisania i czytania, przeł. M. Rakoczy, Wydawnictwa UW, Warszawa 2010, s. 18. 


\section{Abstract}

\section{Klaudia Muca}

JAGIELLONIAN UNIVERSITY (CRACOW)

Spelling out the Gaps of the Everyday: The Contexts of Narratives on Aphasia

Individuals who have experienced aphasia often create narratives about beginnings about relearning language and cultural codes, about finding one's bearings in space, about expressing experiences. Many of these narratives form an idiom of personal experience, an account of regaining oneself through language. In this article Muca describes and analyses the work of Karolina Wiktor. Wiktor portrays her episode of aphasia as an experience of a deficiency, loss and renewed creation, through the smallest particles of words, that is to say letters, coming together as a narrative about'an explosion of the brain'. For an aphasiac, the creation of a narrative is a sort of (self-)therapy. Analysing such accounts allows us to tackle fundamental questions about cognition, such as the relationship between language and the creation of identity.

\section{Keywords}

aphasia, narrative, spelling, language, identity, communication, experience, therapy, stroke 